\title{
WHAT MAKES SECOND LANGUAGE ACQUISITION COMMUNICATIVE POWER: NATURE? NURTURE? INTERACTION? OR ALL TOGETHER? PRAGMATIC APPROACH TO TESOL IN COMPARATIVE MULTILINGUAL PRACTICES
}

\author{
Eshchanov Marat Urazaliyevich \\ Assistant Professor of English as a foreign language TESOL and TESP certified Teacher \\ and Teacher Trainer Researcher in TESOL and Anglo-American Philologies \\ Department of Natural and Humanitarian Sciences, Samarkand Veterinary
}

Medicine Institute's Nukus Branch

Article DOI: https://doi.org/10.36713/epra9084

DOI No: 10.36713/epra9084

\begin{abstract}
The article discusses theories of second language acquisition within the framework of nature, nurturing, and interactionist views to language learning and reveals the results of their application to non-native multilingual people's language acquisition experiences in communicative and meaningfully absorbing environments. The research proposes the necessary space for the discussion of practicality and authenticity of nature, nurture and interactionist theories in language learning, which can be conducted as an integral examination of second language learner efficacy.

KEY WORDS: second language, acquisition, nature, nurture, interactionist, technique, authentic, skill and knowledge, experiences, environments, learn, acquire, comprehensible input and output, meaningful language acquisition, autonomous learning
\end{abstract}

\section{INTRODUCTION}

In the first and second language acquisition, nature, nurture and interactionist perspectives occupy a prominent place and generate more controversy in terms of relevance and appropriateness. The importance of nature, nurture and interaction lies in the big demand they present for the assessment of their appropriacy for practices in second language acquisition.

The nature theory shows that a child is born with an innate knowledge of or inclination to language and that innateness is specific for all human beings. Nativists believe that language is a set of habits which can be acquired by a process of conditioning or by sets of programs through which a child's language is developed and acquired according to a biological timetable whereas linguists and psychologists argue that adherence to such a definition can obstruct an immediate or effective acquisition in terms of nurturing language.

\section{MAIN BODY}

To discuss the relevance of these theories to the real practices in language acquisition, it would be advisable to present some experiences on the question and the field. Douglas Brown (2007) holds the view that 'innateness hypothesis' leaves room for hard evidence for language genes and suggests a little remoteness from the 'innateness' while it is possible to consider more important factors other than biological ones for developing the first and second language acquisition. Dr. Brown said, "We must not 


\section{EPRA International Journal of Research and Development (IJRD)}

put all our eggs in the innateness basket. Environment factors cannot by any means be ignored as connectionists and emergentists have shown". He also emphasizes the controversial features of "naturenurture' views among language researchers, psychologists and educators. According to D. Brown, 'nature' provides innately in some sort of predetermined timetables.

I believe that 'nurture' perspective should be a central issue of SLA due to the unique social and linguistic features and opportunities it presents to language learners and educators in many ways. 'Nurture' should be viewed as environmental exposure to language through teaching, learning and internalization. Though language acquisition is universal in children, the environmental factors have more support of the efficiency of language acquisition in terms of interaction with the environment, people, surrounding, tasks, teachers, learners, experiences and others. Those researchers who contradict the nurture perspective heavily depend on the interrelation between linguistic and cognitive development, which often lacks genuine experience, relevant assessment and specificity. One such study was carried out by Derek Bickerton (1981), who suggested that individuals are programed to release specific language at certain developmental ages. He said, "Just as we cannot make a geranium bloom before its 'time', so human beings will 'bloom' in predetermined, programed steps".

Different from other linguists and researchers in his attitude towards the place of 'innateness'-'nature', Pinker (2006) claims that the cognitive tasks like representing objects or ideas mentally are the necessary components and tools for language development. He argues that people's operation with the mind, the ability to attribute mental states, such as beliefs, intents, desires and understanding them, takes place with the language instinct. Pinker could be right to a certain extent with his 'operational 'views, but I think that they lack support for making a clear distinction between the brain and language process within the framework of operational technique.

In my view, Douglas Brown appears to offer a relevant idea based on hands-on experiences with language acquisition when he says "we do know is that adults and children alike appear to have the capacity to acquire a second language at any age. The only trick that nature might play on adults is to virtually rule out the acquisition of authentic accent". This incapability may arise from intervening cognitive and affective variables, so it unmarks the absence of innate abilities.

With a big communicative role in SLA theories and practices, 'interactionist' approach reflects and presents not only children's innate properties but also the impact of child's experience on language acquisition and its response to cognitive and social development operations. According to 'interactionist approach' adherents, there are specific brain structures to promote language acquisition in late learners, which enables them to acquire a language with the influence of kinds of skill and knowledge rather than innate capability. I think that these proponents refer to and place emphasis on the ability to learn and acquire a language in different suitable and multi-functional space (environments). This attitude generates greater interest in identifying and emphasizing the importance of interaction in the necessary language environments within SLA. The 'interactionist' paradigm is interpreted in terms of cognitive interactionist and social-interactionist views. All of these perspectives presume that the child brings simple preexisting information to the task of language learning and its environmental input plays a significant role in its language development. While experiencing language in a specific situation (interaction), the child develops attention, sensation, speech perception, syntactic processing and memory storage with which, it also experiences sociopragmatic skills such as listening attentively, turntaking, repeating, clarifying, praising, complaining, expressing emotions, attitudes and others.

As discussions go about the place of interactionist views in SLA, I would like to support my ideas with some research evidence and my personal experiences. Jacqueline Sacks and her colleagues (1981) studied the language development of a child called Jim. He was a hearing child of deaf parents, and his only contact with oral language was through television. The family was unusual in that the parents did not use the sign language with Jim. Thus, Jim did not begin his linguistic development in a normal environment. The language assessment showed that he had experienced ideas appropriate to his age, but he used unusual and ungrammatical word order. Jim's progress with language began with an adult. As a result of his contact with the adult, his expressive abilities began to improve. By the age of four years and two months, his unusual speech patterns had replaced by structures more typical of his age. The research shows that Jim's very rapid acquisition of English structures attributed to his interaction with an adult on a one to one basis. This example supports 'interactionist perspective' in a way that children can learn and acquire a language best through interaction: repetition and paraphrasing.

From my personal observations in life, I would say that nurturing and interaction have more to best promote language acquisition. Before becoming a linguist, I wondered how my nieces acquired Russian as a native language despite their different nationality, culture and family language and never used their mother tongue (native language). They 


\section{EPRA International Journal of Research and Development (IJRD)}

were raised in a bilingual family, where its members spoke two differently structured languages, one Central Asian, the other - Russian in some parts of their daily home dialogues. Later, I found out that not the nature ('innateness') but the nurture and interaction (grandmother's frequent use of Russian in conversations) had largely influenced their Russian language acquisition. Besides this, the girls' continuously hearing the melody of Russian in their contact and experience with parents, family (grandmother), kindergarten, school, teachers, listening and reading in the target language and others had developed their ability to acquire language meaningfully. So had their inspiration by the target language environment and confidence to accept and use it as a native language.

Rebecca Oxford developed certain ways of exposure to the language, which she called foreign language learning strategies. Oxford (1990) argues that learning strategies such as metacognitive, affective, social, memory, cognitive and compensation strategies must both help learners participate in communication and build up language system.

Based on the reading, viewing and research conducted, it would be desirable to list some other effective language learning strategies or techniques as below. For language learners wishing to pursue and speak different languages, the below-mentioned techniques could be effective if they were selected according to communicative goals or situations.

$>$ plan language learning

$>$ work on language learning and acquisition tasks with other people (e.g. friends, native speakers, teacher, people on the course, tourists) as well

$>\quad$ try to find opportunities to practice speaking (even to yourself) to improve fluency

$>$ review independent study program regularly and change it when you find deficiencies

$>$ try to personalize your language learning

$>$ use technology and media as well as comprehension input

$>$ use gestures when you cannot describe certain actions

$>$ make associations or use spatial memory techniques

> use visual representations (Venn diagrams, time lines, charts, color-coding) of important relationships between concepts

$>$ attempt concept check

$>$ welcome feedback for improvement

To learn multiple languages in my early school and adult university life, I used various communicative inputs that could enable me to acquire foreign languages such as English, Russian and Italian in meaningful ways. By inputs, I mean the messages and sources for my language acquisition and variables that positively influenced my language learning. During my early language acquisition at school, I used the teacher, learners, texts, translations, talks, dialogues, lesson reviews, conversations with native speakers and tourists as the useful sources for developing my accuracy and fluency. Though Stephen Krashen suggests second language acquisition through meaningful interaction without grammatical drill, I need to say that I had to utilize little grammar for drilling and recognizing the structure and meaning due to the content in the required syllabus. I tried to practice speaking, even to myself to sustain engagement in native-like English conversations. More significantly, I made frequent use of review as to monitor my independent study program and motivation by setting specific and target goals for English use.

What made my Italian language acquisition different from my early language learning experience was my constant talk with two Italian native speakers, my undergraduate Italian program instructors who established good rapport and authentic interaction with me and other learners. While learning and endeavoring to acquire the Italian language, I saw my teachers, other learners and interactive classroom tasks, visits to opera, Italian cultural festivals, and extracurricular activities in Italian as the most comprehensible input and output which generated my interest in meaningful language acquisition and which promoted my autonomous learning. I tried to learn from the mistakes I made too.

\section{CONCLUSION}

In conclusion, it can be stated that second language acquisition best attributes to the input as well as to motivation in the environment and other positive personal traits. Another notable aspect of the subjects' second language acquisition was found to be their ability to passionately initiate, to develop and support interaction with adults, family, language teachers, learners and native speakers. From the research conducted with non-native second language speakers, I conclude that reflective experience with comprehensible input in languages as a child, school student greatly benefited the subjects' language acquisition. That was they had acquired language by subconsciously using natural learning strategies such as guessing words and structures from context and inferring their meanings. This helped them later produce language and present comprehensible output in authentic and intercultural communications with more confidence and more sensible linguistic means.

It is also necessary to imply that the issue of language learning technique or strategy in second language acquisition is complex, and there are no simple solutions to the questions of how to promote efficient employment of techniques and strategies. 


\section{EPRA International Journal of Research and Development (IJRD)}

Volume: 6 | Issue: 12 | December 2021

- Peer Reviewed Journal

What is more significant is teacher's sensitivity to the ways in which their learners learn, their attitudes towards teaching their learners to think and to learn, and an awareness of the part of the learners must play in taking control of their learning.

\section{REFERENCES}

1. Brown, H. Douglas. (2007). Teaching by Principles: An Interactive Approach to Language Pedagogy. New York: San Francisco State University.

2. Brown, J. (1998). Understanding Research in second language learning: A teacher's guide to statistics and research design. Cambridge: Cambridge University Press.

3. Crystal, David. (1997). The Cambridge Encyclopedia of Language. Cambridge: Cambridge University Press.

4. Dudley-Evans, T. and St John, M. J. (1998). Developments in English for Specific Purposes. Cambridge: Cambridge University Press.

5. Hutchinson, T., and Waters, A. (1987). English for Specific Purposes: a Learning-centered Approach. Cambridge: CUP.

6. Jarvis, H., \& Krashen, S. (2014). Is CALL Obsolete? Language Acquisition and Language Learning Revisited in a Digital Age. TESL-EJ.

7. Eshchanov M.U. (2021). Bridging the language gap with online materials and resources in TESOL. ICT In Education: Challenges and solutions. International Conference Proceedings. Tashkent.

8. Oxford, R. (1990). Language Learning Strategies: What Every Teacher Should Know. New York: Newbury House.

9. Tomlinson, B. (1998). Materials development in language teaching. Cambridge: Cambridge University Press. 